\title{
Discovery of Potent Benzofuran Derived Diapophytoene Desaturase (CrtN) Inhibitors with Enhanced Oral Bioavailability for the Treatment of Methicillin-Resistant $S$. aureus (MRSA) Infections
}

Youxin Wang ${ }^{\mathrm{a}, \dagger}$, Feifei Chen ${ }^{\mathrm{b}, \dagger}$, Hongxia $\mathrm{Di}^{\mathrm{b}}$, Yong Xuc $\mathrm{Xu}^{\mathrm{c}}$, Qiang Xiao ${ }^{\mathrm{c}}$, Xuehai Wang ${ }^{\mathrm{d}}$, Hanwen Wei ${ }^{\mathrm{a}}$, Yanli Lu ${ }^{\mathrm{a}}$, Lingling Zhang ${ }^{\mathrm{a}}$, Jin Zhu ${ }^{\mathrm{a}}$, Chunquan Sheng ${ }^{\mathrm{e}}$, Lefu Lan ${ }^{\mathrm{b}, *}$, $\operatorname{Jian} \mathrm{Li}^{\mathrm{a}, *}$

${ }^{a}$ Shanghai Key Laboratory of New Drug Design, School of Pharmacy, East China University of Science and Technology, Shanghai 200237, China

${ }^{\mathrm{b}}$ State Key Laboratory of Drug Research, Shanghai Institute of Materia Medica, Chinese Academy of Sciences, Shanghai 201203, China

${ }^{c}$ Hubei Bio-pharmaceutical Industrial Technological Institute Inc., Wuhan 430075, China

${ }^{\mathrm{d}}$ Humanwell Healthcare (Group) Co. Ltd, 666 Gaoxin Road, Wuhan 430075, China

${ }^{\mathrm{e}}$ Department of Medicinal Chemistry, School of Pharmacy, Second Military Medical University, Shanghai 200433, China.

${ }^{\dagger}$ These authors contributed equally to this work.

* To whom correspondence should be addressed. jianli@ecust.edu.cn or 1lan@simm.ac.cn 


\section{Supporting Information}

HPLC analysis data of compounds 1-2, 3a-c, 4a-f and 5a-u

Table S1. HPLC analysis data of compounds 1-2, 3a-c, 4a-f and 5a-u. The purities of identified compounds that was essential to the conclusions drawn in the text, and determined by a standard instrumentation with one system given in the following table. The peak purity was checked with UV spectra.

\begin{tabular}{|c|c|c|c|}
\hline \multicolumn{2}{|c|}{ Equipment } & \multicolumn{2}{|c|}{ Agilent 1100 with quaternary pump, diode-array detector (DAD), } \\
\hline \multicolumn{2}{|c|}{ Column } & \multicolumn{2}{|c|}{ Agilent Exlipse XDB-C18 $(250 \times 4.6 \mathrm{~mm}, 5 \mu \mathrm{m}$ particle size $)$} \\
\hline \multirow{2}{*}{\multicolumn{2}{|c|}{ System condition }} & $\begin{array}{l}\text { a. } \\
\mathrm{CH}_{3} \mathrm{OH} / \mathrm{H}_{2} \mathrm{O}\left(0.1 \% \mathrm{H}_{3} \mathrm{PO}_{4}\right), \\
90 \%(\mathrm{v} / \mathrm{v}) \text { of } \mathrm{CH}_{3} \mathrm{OH} \text { gradient, } \\
\text { flow rate: } 0.5 \mathrm{~mL} / \mathrm{min}, \\
\text { calculated the relative purity of } \\
\text { each compound at } 280 \mathrm{nM}\end{array}$ & $\begin{array}{l}\text { c. } \\
\mathrm{CH}_{3} \mathrm{OH} / \mathrm{H}_{2} \mathrm{O}\left(0.1 \% \mathrm{H}_{3} \mathrm{PO}_{4}\right), \\
90 \%(\mathrm{v} / \mathrm{v}) \text { of } \mathrm{CH}_{3} \mathrm{OH} \text { gradient, } \\
\text { flow rate: } 1.0 \mathrm{~mL} / \mathrm{min} \text {, calculated } \\
\text { the relative purity of each } \\
\text { compound at } 280 \mathrm{nM}\end{array}$ \\
\hline & & $\begin{array}{l}\text { b. } \\
\mathrm{CH}_{3} \mathrm{OH} / \mathrm{H}_{2} \mathrm{O}\left(0.1 \% \mathrm{Et}_{3} \mathrm{~N}\right), 90 \% \\
(\mathrm{v} / \mathrm{v}) \text { of } \mathrm{CH}_{3} \mathrm{OH} \text { gradient, flow } \\
\text { rate: } 0.5 \mathrm{~mL} / \mathrm{min} \text {, calculated the } \\
\text { relative purity of each } \\
\text { compound at } 280 \mathrm{nM}\end{array}$ & \\
\hline \multirow{21}{*}{ Results } & Compd & Retention time $(\mathrm{min})$ & Relative purity (\%) \\
\hline & $\mathbf{1}^{\mathrm{a}}$ & 4.53 & 100 \\
\hline & $2^{b}$ & 8.96 & 97.0 \\
\hline & $3 \mathbf{a}^{\mathrm{a}}$ & 4.66 & 97.3 \\
\hline & $3 \mathbf{b}^{\mathrm{a}}$ & 4.70 & 95.2 \\
\hline & $3 c^{a}$ & 4.69 & 95.1 \\
\hline & $4 a^{a}$ & 4.71 & 96.7 \\
\hline & $4 b^{a}$ & 4.72 & 95.4 \\
\hline & $4 c^{a}$ & 4.68 & 95.2 \\
\hline & $\mathbf{4} d^{\mathrm{a}}$ & 4.70 & 98.4 \\
\hline & $4 e^{a}$ & 4.97 & 95.0 \\
\hline & $4 f^{a}$ & 4.68 & 95.0 \\
\hline & $5 \mathbf{a}^{\mathrm{a}}$ & 4.65 & 96.0 \\
\hline & $5 \mathbf{b}^{\mathrm{a}}$ & 4.75 & 95.8 \\
\hline & $5 c^{c}$ & 2.28 & 95.3 \\
\hline & $5 d^{a}$ & 4.62 & 99.2 \\
\hline & $5 e^{a}$ & 4.60 & 95.6 \\
\hline & $5 f^{a}$ & 4.68 & 97.8 \\
\hline & $5 g^{\mathrm{a}}$ & 4.59 & 97.2 \\
\hline & $5 h^{a}$ & 4.36 & 96.4 \\
\hline & $5 i^{a}$ & 4.41 & 95.1 \\
\hline
\end{tabular}




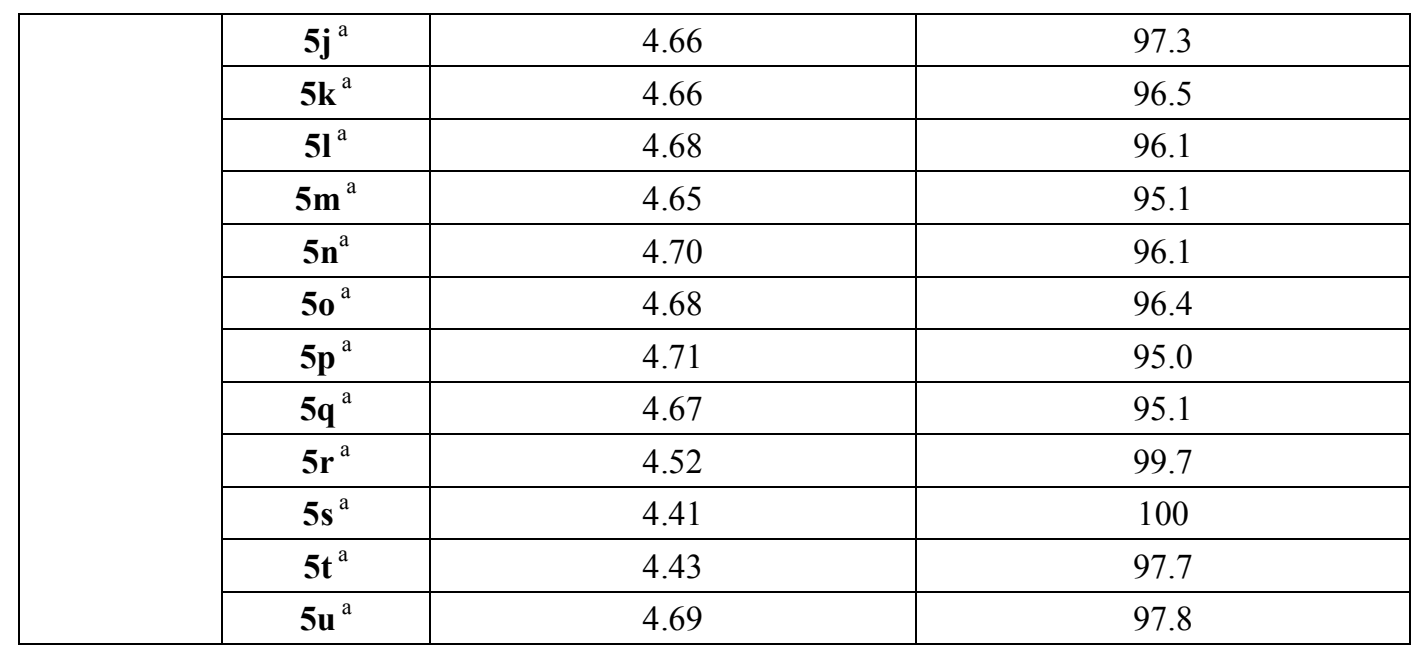

\section{Cell proliferation assay}

Two normal human cell lines, human microvascular endothelial cells (HMEC) and human pulmonary fibroblast cells (WI38), were purchased from American Type Culture Collection (Manassas, VA). Cells were cultured according to the suppliers' instructions. Then cells were plated into 96-well plates in complete medium. After incubation overnight, cells were exposed to various concentrations of compound $\mathbf{5 m}$ for further $72 \mathrm{~h}$. Cell proliferation was evaluated by SRB (sulforhodamine B, Sigma) assay. $\mathrm{IC}_{50}$ values were calculated by concentration-response curve fitting using a SoftMax pro-based four-parameter method. Each $\mathrm{IC}_{50}$ value was expressed as mean \pm SD.

\section{hERG assay}

\section{Cells preparation}

hERG potassium channels stably expressing $\mathrm{CHO}$ cells were grown at $37^{\circ} \mathrm{C}, 5 \% \mathrm{CO}_{2}$ incubator to a maximum confluence of $70-80 \%$. On the assay day, cells were washed with $7 \mathrm{~mL}$ PBS then digested with $3 \mathrm{~mL}$ Trypsin, place the culture flask in a $37^{\circ} \mathrm{C}$ incubator for $\sim 2$ min, add 5 $\mathrm{mL}$ serum-free media and resuspend the cells by pipette the cells suspension up and down. Pellet the cells by centrifuge at $800 \mathrm{rmp}$ for $3 \mathrm{~min}$, remove the supernatant and resuspend the cells with suitable volume of extracellular solution to make sure that there are $2-5 \mathrm{mill} / \mathrm{mL}$ cells loaded to the Qpatch.

2. Solutions

\begin{tabular}{|l|l|l|}
\hline Reagents & External Solution $(\mathrm{mM})$ & Internal Solution $(\mathrm{mM})$ \\
\hline $\mathrm{CaCl}_{2}$ & 2 & 5.374 \\
\hline $\mathrm{MgCl}_{2}$ & 1 & 1.75 \\
\hline $\mathrm{KCl}$ & 4 & 120 \\
\hline $\mathrm{NaCl}$ & 145 & - \\
\hline Glucose & 10 & - \\
\hline HEPES & 10 & 10 \\
\hline
\end{tabular}




\begin{tabular}{|l|l|l|}
\hline EGTA & - & 5 \\
\hline Na-ATP & - & 4 \\
\hline $\mathrm{pH}$ & $\begin{array}{c}7.40 \text { (adjusted with } \mathrm{NaOH} \text { ), } \\
\text { Osmolarity } 305 \mathrm{mOsm}\end{array}$ & $\begin{array}{c}7.25 \text { (adjusted with } \mathrm{KOH} \text { ), } \\
\text { Osmolarity } 290 \mathrm{mOsm}\end{array}$ \\
\hline
\end{tabular}

All reagents were purchased from Sigma, purity $>98 \%$

3. Qpatch experiment

Whole-cell recordings were performed using automated Qpatch (Sophion). Cells were voltage clamped at a holding potential of $-80 \mathrm{mV}$. The hERG current was activated by depolarizing at $+20 \mathrm{mV}$ for $5 \mathrm{~second}$ (sec), after which the voltage was taken back to $-50 \mathrm{mV}$ for 5 sec to remove the inactivation and observe the deactivating hERG tail current. The voltage stimulation was applied per $15 \mathrm{sec}$. Compounds solutions were administrated from low to high concentration, $2 \mathrm{~min}$ for each concentration and $10 \mu \mathrm{M}$ cisapride was applied at the end of perfusion of compound solution. Each concentration was tested on at least 3 cells.

4. Compounds preparation

Compound was prepared to a DMSO stock of $20 \mathrm{mM}$. On the assay day, compound was diluted to the final concentrations with extracellular solution. Compound final concentrations were $40,8,1.6,0.32,0.064,0.0128 \mu \mathrm{M}$. For positive control, cisapride was tested at a maximum concentration of $3 \mu \mathrm{M}$, final concentrations were 3, 0.6, 0.12, 0.024, 0.0048 and $0.00096 \mu \mathrm{M}$. DMSO is less than $0.2 \%$ in the final compounds solutions. It has no effects on hERG currents.

5. Data Analysis

Data were analyzed using Assay Software provided (Sophion) and XLFit.

6. Quality Control

Data included in the report originated from experiments which satisfied all of the following criteria:

Recording parameters

- temperature: $22 \sim 25^{\circ} \mathrm{C}$, humidity: $20 \sim 50 \%$

- membrane resistance $\mathrm{Rm}>100 \mathrm{M} \Omega$

- tail current amplitude $>200 \mathrm{pA}$

Pharmacological parameters

Inhibition of cisapride on hERG current as positive control. 